\title{
RESEARCH PAPER \\ THE VULNERABILITY OF PERI-URBAN FARM HOUSEHOLDS WITH THE EMERGENCE OF LAND MARKETS IN ACCRA
}

\author{
C. Y. Oduro and R. Adamtey \\ Department of Planning, KNUST, Kumasi \\ Corresponding author: yawoduro68@gmail.com \\ Email:radamteysekade@gmail.com
}

\begin{abstract}
Accra, the capital of Ghana, is a fast-growing African city. Its growth has brought in its wake an ever-increasing demand for land, which has in turn led to the emergence of a land market that is increasingly supplanting the age-old customary land tenure system. The customary land tenure system is based on communal, rather than individual ownership of land. However, over the last few decades, the system has come under pressure from the forces of rapid urbanization, city expansion and increasing demand for land for urban development. The purpose of this paper was to examine the vulnerability of residents of indigenous communities in peri-urban Accra due to the emerging urban land market. The case study approach has been used to explore vulnerability among residents of two indigenous communities in peri-urban Accra in respect of their ability to access land. Household surveys, focus group discussions and key informant interviews involving community members, leaders and municipal officials were the main techniques used to collect data. The study revealed that indigenous and long-term residents had their farmlands converted to urban development without any measures in place to protect them from the collapsing customary land tenure system and the evolving urban land market. This has negatively impacted their quality of life, especially with respect to livelihoods. There is therefore the need for municipal assemblies to include the preservation of farmlands in the management of physical growth and land use so as to minimize the rate at which farmlands are being converted to urban development. Measures should also be put in place to restore farm households that have lost their land to urban development in the form of compensation and provision of alternative livelihoods.
\end{abstract}

Keywords: Vulnerability, customary, land tenure, urban growth, land market

The population of Accra, the capital of Ghana, grew from 377,446 in 1960 (Twum-Baah, 2000) to 2,076,546 in 2010 (Ghana Statistical Service [GSS], 2013). Its growth has over the years spilled over into adjoining municipalities within the Greater Accra Metropolitan Area (GAMA)(Fig. 1). This has brought in its wake an ever-increasing demand for land leading to 
the emergence of a land market that tends to supplant an age-long customary land tenure system.

The customary land tenure system is egalitarian and based on communal ownership of land, with its underlying principles being equity, fairness and security (Mends and De Meijere, 2006: 5). For example, among the Ga people (the indigenes of Accra), Quarcoopome (1992:
41) points out that,

Members of the corporate group and strangers who require plots to build on, to settle on or to farm on, approach the elders of the group for the purpose. Upon the performance of the necessary ritual, which involves provision of drinks for libation to the gods and the ancestors; the payment of a token fee, the value of which depends on

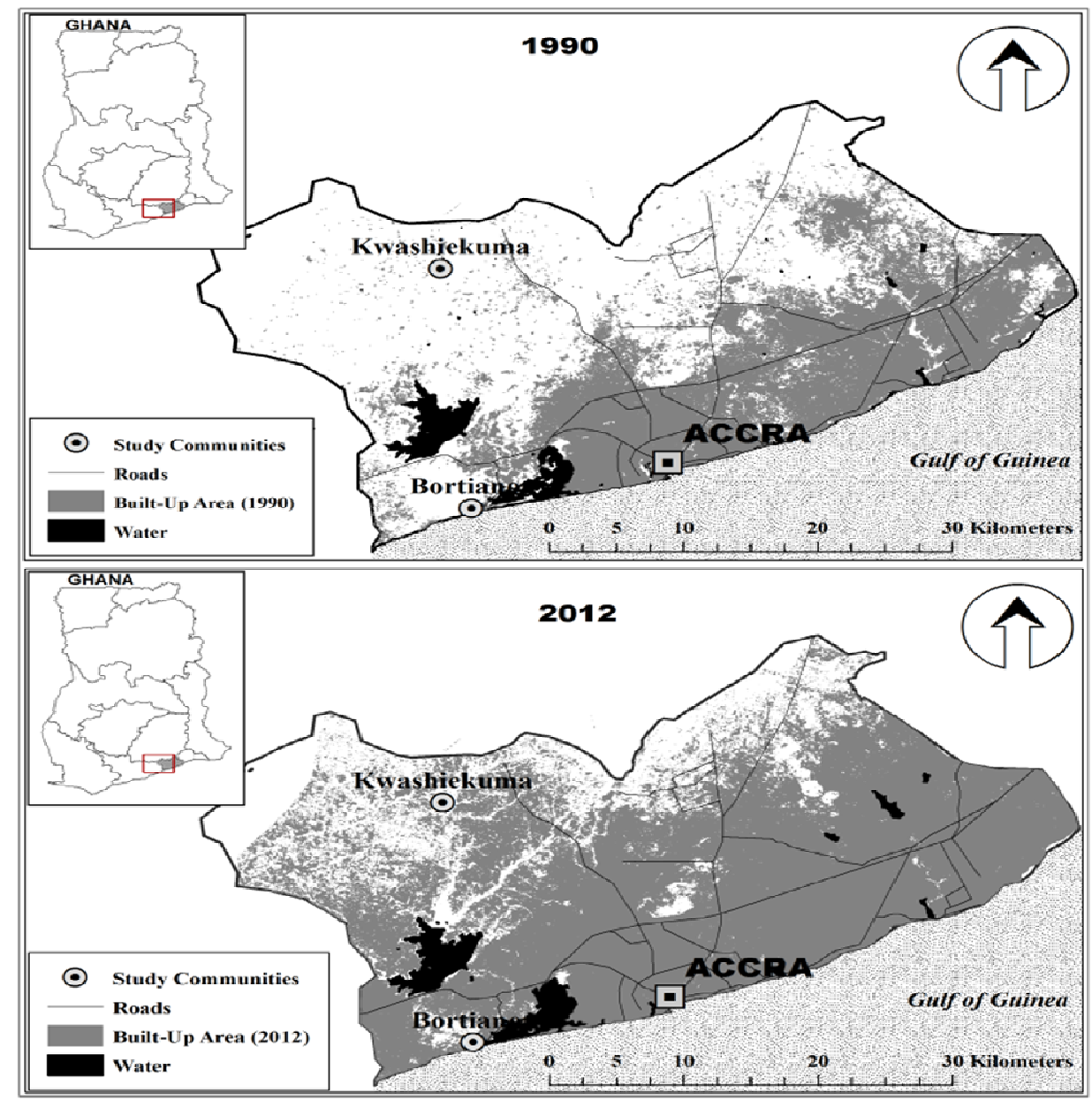

Fig. 1: Map of GAMA showing study communities and built-up area in 1990 and 2012 Source: Authors' construct 
the right in the land being demanded; and upon the slaughter of a sheep, the land is allocated.

This system has over the centuries guaranteed that both indigenes and migrants have access to land for shelter and farming (Mends and De Meijere, 2006; Quarcoopome, 1992). However, over the last few decades, the system has come under pressure from the forces of rapid urbanization and increasing demand for land (Aryeetey et. al., 2007). Consequently, the traditional tenets of communalism, equity and inter-generational security are rapidly giving way to a poorly regulated urban land market fraught with chaos.

What has happened to tenure security for the residents of indigenous peri-urban communities who depend directly on land to make a living, against the backdrop of the above developments? While a lot has been written on Africa's customary land tenure system (e.g. Aryeetey et. al., 2007; Mends and De Meijere, 2006; Nkwae, 2006) and urban land markets (e.g. Antwi and Adams, 2003; Kassanga et. al., 1996; Mahama and Antwi, 2006), not much has been done on the vulnerability of peri-urban residents due to the collapse of the customary land tenure system and the emergence of the urban land market. Our purpose in this paper is to examine the vulnerability of residents of indigenous communities in peri-urban Accra due to these two simultaneous developments. We have used two peri-urban communities in the GAMA, Kwashiekuma and Bortianor, as case studies.

\section{CONCEPTUAL FRAMEWORK}

\section{Overview of the customary land tenure sys-} tem

About $78 \%$ of Ghana's total land is made up of customary lands (Mends and De Meijere, 2006) with varying titles (Ollennu, 1962). For example, the Paramount (Allodial) title is vested in a 'community' - a family, clan, village, township, etc. In most cases, when the title is vested in a village, township or a group of villages and townships, the ultimate owner of the land under this title is a stool or skin. Chiefs who are the occupants of stools or skins hold the title in trust for their subjects as long as they occupy that hereditary office. However, in many parts of Northern Ghana, allodial title is vested in land priests called tindanas (see Dordaa, 2012; Bugri, 2008; Kasanga, 1998). When the title is vested in a family or clan, the said land is called 'family land' and the title is held by the head of that family or clan in trust for his subjects. Although the chief, tindana or family/ clan head can make a grant to an individual, as Nana Sir Ofori Atta described it, the land "belongs to a vast family of whom many are dead, a few are living and countless hosts are still unborn" (cited in Ollennu, 1962: 4).

The Determinable or Usufructuary title refers to the right of individuals or lineages to enjoy land held under a paramount title by virtue of their being bonafide members of the community or family that owns the land (Blocher, 2006; Ollennu, 1962). The holder of this title may not have the right to transfer it to a 'stranger', but his/her descendants may automatically inherit the title upon his/her death (Blocher, 2006; Kassanga et. al., 1996), depending on the title holder's gender and whether the community in question practices the patrilineal or matrilineal system of inheritance. The Gas in the study area and other ethnic groups in Ghana practice the patrilineal system in which children inherit determinable titles through their father.

\section{Emergence of the urban land market}

In the past, the various forms of tenure under the customary system made it easy for community members and 'strangers' to gain access for various purposes. Land transactions usually involved a 'drink' presented by the title recipient to the chief or clan/family head (Mends and De Meijere, 2006). Since customary lands were not sold, the drink did not represent the price of the land; it was meant to bind the parties involved in the transaction as well as enjoin the gods, ancestors and all who consumed it to be 
witnesses to the said transaction (see Quarcoopome, 1992). In other words, land was not considered a commodity to be exchanged for money profit.

However, because of increasing demand for land, the consideration of land as a 'social good' is increasingly giving way to its commercialisation, particularly in urban and peri-urban areas (see Grant, 2007). The emerging land market allows individuals (including 'strangers') to acquire land based on their ability to pay a price that is determined purely by the forces of demand and supply. In peri-urban Accra, chiefs and clan/family heads now find it lucrative to lease farmlands to developers and speculators who can pay high premiums. The shift from customary tenure towards land market has the potential to foster economic development (Nkwae, 2006), as predicted by the evolutionary theory of land rights (ETLR). The theory postulates that population growth leads to increased demand for and value of land up to a point where communal ownership becomes unstable and "economic efficiency justifies the replacement of communal by private ownership rights" (Platteau, 1996: 31). However, in the case of Sub-Saharan Africa, the economic benefits of this evolutionary shift are often exaggerated by proponents of the ETLR (Platteau, 1996). For example, because proceeds from the lease of land are often distributed among chiefs or clan/family heads and a few inner-core elders to the neglect of other members of the community or family (Kassanga et. al., 1996), disputes over who is entitled to the proceeds now abound (Mends and De Meijere, 2006). There are also rampant disputes among communities, rival chiefs, families and individuals over land boundaries and ownership (Quarcoopome, 1992).

\section{Concept of vulnerability}

According to Moser (1996 cited in Rakodi, 2002), vulnerability refers to the insecurity of an individual, household or community's wellbeing as a result of changes in the ecological, economic, social and political environments. It is the ability, or inability, to withstand "sudden, unpredictable and traumatic" events, which are also called shocks (Krantz, 2001: 7). Examples include fire outbreaks, storms, floods, droughts, epidemics and civil conflicts. Vulnerability can also stem from trends (i.e. continuous, cumulative and predictable events) such as urbanization and other demographic changes, or from seasonality, which refers to cyclically recurring events such as periodic changes in weather and food prices (Twigg, 2001). Also related to vulnerability is the concept of resilience, which refers to the ability to "mobilize assets to exploit opportunities and resist or recover from the negative effects of the changing environment" (Rakodi, 2002: 14-15).

As depicted in Fig. 2, we consider the emergence of the urban land market and the gradual collapse of the customary land tenure system as forms of trends that can lead to insecurity in the well-being of peri-urban residents. Rapid urban growth has resulted in the emergence of an urban land market and the collapse of the customary land tenure system, the interplay of which either impedes or enhances access to land. As DFID's sustainable livelihood framework points out, land is a key component of natural capital. This, together with other livelihood assets (namely financial, physical, social and human capital) is required by indigenous and long-term residents of peri-urban communities to eke a living through various livelihood strategies (see DFID, 1999; Rakodi, 1999; 2002). Thus, any change in residents' access to land will eventually affect the nature and adequacy of their livelihood strategies, either positively or negatively. This will in turn have consequences for their socio-economic wellbeing. Besides being a livelihood asset, land also plays an important role in defining "the identity, integrity, solidarity and culture of any group of African people" (Quarcoopome, 1992: 40). Therefore, any changes in how land is transacted would directly impact the socio-cultural dimensions of their lives, and ultimately their wellbeing (Fig. 2). 


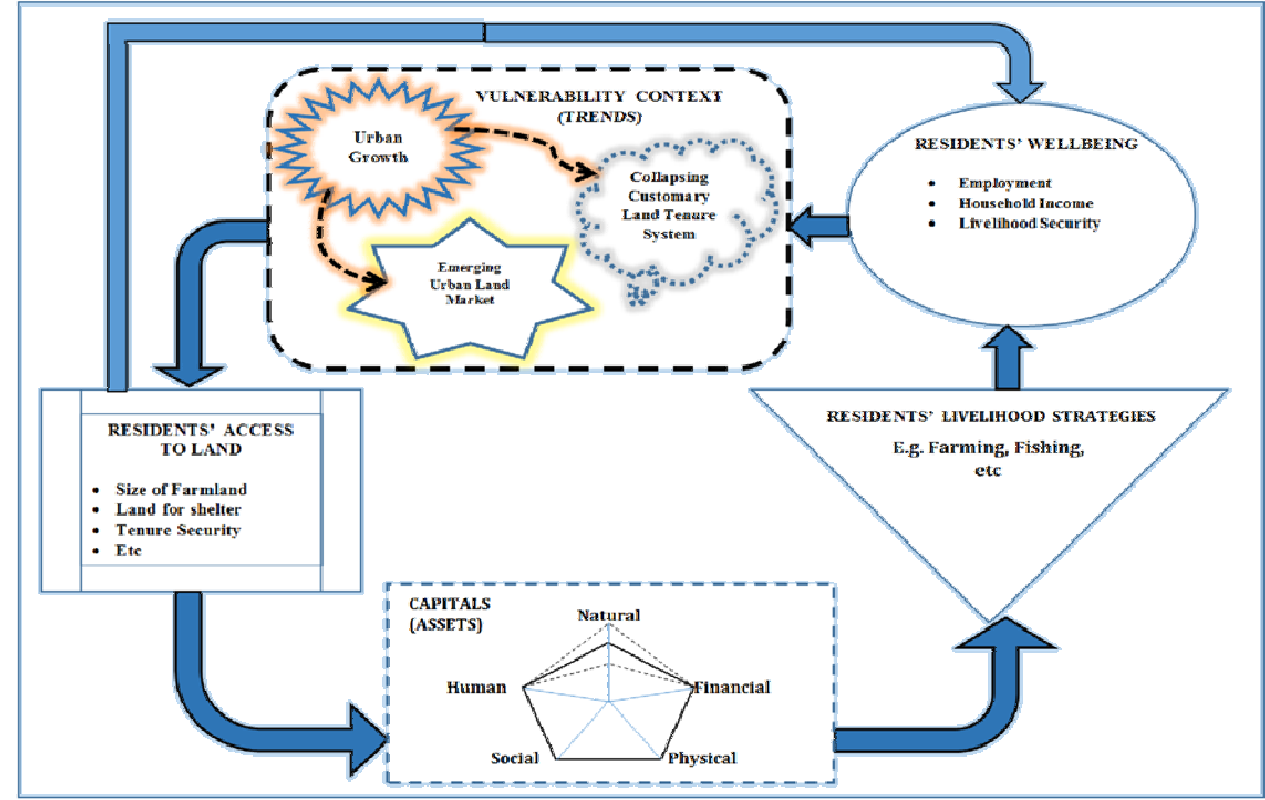

Fig. 2: Conceptual Framework on vulnerability due to emerging urban land market

Source: Authors' construct based on ideas from DFID's Sustainable Livelihood Framework (DFID, 1999)

\section{METHODOLOGY}

The case study approach was adopted in this study. The approach is suitable for studies that seek to answer "how" or "why" questions (Yin, 2003), or test a theoretical model in a realworld situation (Shuttleworth, 2008). Its strength lies in in-depth analysis of complex, contemporary phenomena in their real-life context using evidence from multiple sources. Exploring and documenting the vulnerability of residents of indigenous peri-urban communities to risks imposed by changes in land tenure, and how this impacts their wellbeing, fits these criteria. Two communities in peri-urban Accra were used for the study.

\section{Description of the cases}

The two study communities, which represent different locational, socio-economic and administrative contexts in peri-urban Accra, are Kwashiekuma and Bortianor. Although it is located within the peri-urban zone of Accra,
Kwashiekuma is not a typical peri-urban community in the sense that it has not yet experienced the kind of rapid growth in population and residential development usually found in other peri-urban communities. According to census reports, the population of the village stood at 566 in 1984 but declined to 403 in 2000; its population in 2010 is estimated at only 445. However, it represents an interesting case of a rural, farming community that is located in the shadow of a fast-growing city and has recently been besieged by city dwellers who are either looking for sand or looking for cheap land to acquire on a speculative basis. The community is located in the Ga West Municipality and is about $30 \mathrm{~km}$ from Accra by road.

According to the Queen mother and elders of Kwashiekuma, the village was founded in the $18^{\text {th }}$ century by one Opanyin Kwasi Kuma. The vast stretch of land on which Kwashiekuma 
and other villages were built was gifted to him by Nii Sempe, one of the paramount chiefs of Accra at the time. As a token of his acknowledgement of Nii Sempe as his landlord, Opanyin Kwasi Kuma paid an annual tribute in the form of corn and other farm produce during the celebration of Homowo. Homowo is an annual festival celebrated by the Gas who are the indigenes of Accra. To date, Kwashiekuma lands are customarily under the Sempe Paramount Stool of Accra.

Over time, the original land allocated to Opanyin Kwasi Kuma was divided among his siblings and their descendants as family lands with a portion retained as stool land. Thus, as is the case in many Ga communities, most of the Kwashiekuma lands are classified as family lands. The heads of the descendant, landowning families are responsible for allocating portions of their respective lands to family members who hold usufructuary title and to outsiders who may be given long-term lease titles or short-term titles as in the case of temporary guest settlers and sharecroppers. Similarly, stool lands are allocated by the chief and his elders. However, whether family land or stool land, all lease agreements are endorsed by the chief to authenticate the transactions.

Throughout its history, crop farming has been the main occupation of the inhabitants. However, the study shows that this livelihood source has been affected in ways that threaten the survival of the inhabitants. Although farming remains the largest employer of the workforce, employing almost half of the adult household members who are in the labour force, its dominance has recently declined due to the conversion of farmlands to urban development. Thus farming is expected to give way to other sectors such as trading (wholesale and retail) and service sooner or later (see Table 1).

Bortianor is a much larger community that has almost borne the full blunt of peri-urbanisation and its associated land use conversion. It is a coastal peri-urban town located on the western edge of the Densu Delta wetlands in the Ga South Municipality. It is about $22 \mathrm{~km}$ from Accra and is the fourth largest settlement in the Ga South Municipality. Its population increased from 2,083 in 1970 to 3,299 in $1984,5,446$ in 2000 and 32,485 in 2010.

According to oral accounts by the chief and his elders, the site of the town was originally (more than hundred years ago) settled by four farmers from Accra - Komotey, Komoteh, Ogbarmey and Klemesu - who were later joined by a fisherman called Bortey. The village was initially called Kokobi, but was later nick-named as Bortey-Annor (meaning "Bortey's Cat") by fish traders, in reference to Mr. Bortey's notorious cat that used to steal their fish. Over time, Bortey-Annor was corrupted as Bortianor. The original Bortianor village consists mainly of indigenous Gas, with Ewes, whose ancestors migrated from the Volta Region and settled at Bortianor as fishermen several decades ago, forming a significant minority.

In addition to having fertile farmlands, Bortianor is endowed with the sea and the Densu

Table 1: Occupational distribution of adult household members who are employed

\begin{tabular}{lcllll}
\hline Community & Agriculture & $\begin{array}{l}\text { Mining \& } \\
\text { Quarrying }\end{array}$ & $\begin{array}{l}\text { Manufacturing \& } \\
\text { Construction }\end{array}$ & Trading & Service \\
\hline Bortianor & $25.2 \%$ & $1.1 \%$ & $10.0 \%$ & $37.3 \%$ & $26.4 \%$ \\
Kwashiekuma & $49.4 \%$ & $8.6 \%$ & $0.1 \%$ & $23.6 \%$ & $18.3 \%$ \\
\hline
\end{tabular}

Source: Field Survey, 2015 
Vulnerability of indigenous communities in emerging urban land markets ... 91

Delta wetlands, which include the lower course of the Densu River, estuaries, lagoons and swamps that are rich in fishery resources. Thus, historically, residents of Bortianor have utilized these natural resources for farming and fishing, making it an important supplier of fish and fresh farm produce to Accra. Crop farming used to be a major occupation for both men and women, while fishing was done almost exclusively by the men, and processing and selling of the fish were done by the women. Crops grown include cassava, maize, yams, pepper, okra, onions, garden eggs and tomatoes.

Farming was further boosted in the 1980s when the government introduced the Weija Irrigation Scheme at Tuba village near Bortianor. Utilizing water from the Densu Lake that was created after the construction of the Weija dam, the project made irrigated plots on a 240-hectare farmland available to farmers from Bortianor and other surrounding villages. However, over the last 25 years, farming and fishing activities have diminished significantly as a result of population growth and conversion of farmlands to urban uses. The irrigation scheme has virtually collapsed, with most of the irrigated farmlands now encroached upon by developers.

\section{Data gathering}

To explore the vulnerability of residents of the two study communities due to the emerging urban land market, data were collected from municipal officials and residents. At the municipal level, semi-structured interview guides were used to conduct key informant interviews (KIIs) with municipal coordinating directors, municipal planning officers, agricultural extension officers, community development officers, and town and country planning officers (Table 2).

At the community level, similar interviews were conducted with chiefs/ heads of landowning families, developers and sand winners. In addition to the KIIs, focus group discussions (FGDs) involving community leaders (made up of assemblymen/women, elders and unit committee members) and farmers were conducted in each community, plus a FGD with fishermen at Bortianor. There was also a household survey involving 30 households in Kwashiekuma and another 65 households in Bortianor. A standardised, structured questionnaire was used for this aspect of data collection. Lastly, several documents were reviewed, including municipal development plans, census reports and reports on other related studies carried out in the target communities or municipalities. The secondary data gleaned through documentary reviews provided insights about the historical, physical, economic and social dynamics of the study

Table 2: Data collection methods used and categories of respondents

\begin{tabular}{lccc}
\hline Data collection method/ respondents & Kwashiekuma & Bortianor & Total \\
\hline Key informant interviews: & & & \\
$\quad$ Municipal officials & 5 & 5 & $\mathbf{1 0}$ \\
$\quad$ Chiefs/ Heads of Land-Owning Families & 2 & 2 & $\mathbf{4}$ \\
$\quad$ Developers & 2 & 2 & $\mathbf{4}$ \\
$\quad$ Sand winners & 2 & - & $\mathbf{2}$ \\
Focus group discussions: & 1 & 1 & $\mathbf{2}$ \\
$\quad$ Community leaders & 1 & 1 & $\mathbf{2}$ \\
$\quad$ Farmers group & - & 1 & $\mathbf{1}$ \\
$\quad$ Fishermen group & & & $\mathbf{9 5}$ \\
Household survey: & 30 & 65 & \\
$\quad$ Households (heads) & &
\end{tabular}

Source: Field Survey, 2015 
communities.

\section{RESULTS \\ Vulnerability due to the emerging land mar- ket}

The study revealed that the indigenous and long -term residents of both Kwashiekuma and Bortianor are highly vulnerable due to the emerging urban land market and the continuing modification of the customary land tenure system, in response to pressure from rapid urban growth. In the past residents who belonged to landowning families in these communities had free access to family lands for farming purposes. Those whose families did not own land easily gained permission from the chiefs or landowning families to temporarily cultivate crops or build shelter. Other ways in which landless farmers gained access to land in the past were share cropping and short-term renting. However, increased demand for land for nonagricultural purposes has now made it increasingly difficult for farmers-including those who belong to land-owning families - to gain access to land under these customary arrangements.

According to municipal and community respondents, the single most significant development that has put pressure on Kwashiekuma's lands during the last ten years is the acquisition of farmlands by Accra-based construction firms and individuals for sand winning. According to one local government official, there is high demand for the type of sand deposits at Kwashiekuma and its environs, and this was corroborated during interviews with some of the sand winners. In addition, land speculators and residential developers are acquiring parcels of land in and around the village for urban development. Consequently, the respondents claim that the economic value of land has increased and traditional authorities and family heads now find it lucrative to release arable lands to sand winners, developers and speculators. Usually, land with sand deposits is first leased to sand winners on a temporary basis, after which it is subdivided and leased out to developers on a long-term basis, usually 99 years.

According to elders of Bortianor, before and during the 1980s when farming and fishing were predominant, there was little pressure on land for residential development because residents of Accra considered the village too remote and rural to settle. During this period, the chief actually made conscious efforts to attract outsiders to settle in the community by offering them free land for residential development. However, everything has changed during the last 25 years, with most of the town's farmlands being acquired for development. The presence of the sea with a sandy beach that attracts holiday makers and a hilly landscape that overlooks the sea have attracted several developments, including up-scale residential structures, beach resorts and hotels, thereby driving up land values.

In the past, land transactions in both Kwashiekuma and Bortianor customarily involved a 'drink' or a token amount called 'drink money', presented by the recipient of any form of land title to the chief or clan/family head. However, information obtained from the key informant interviews and focus group discussions suggest that what is now demanded in the name of 'drink money' is so exorbitant that it actually represents the true market value of land. The respondents claimed that land is now priced beyond the reach of most indigenous residents who can no longer access this basic natural resource under the customary arrangements.

Besides the gradual collapse of the customary land tenure system and conversion of farmlands to urban development, communal peace has been threatened by the emerging urban land market, especially at Bortianor. According to the key informants, including elders of the town and officials of the Municipal Assembly, there are disputes arising from the existence of rival factions that lay claim to the same land. For example, as one municipal official of Ga South Municipality stated, 
Vulnerability of indigenous communities in emerging urban land markets ... 93

Bortianor is noted for chieftaincy and land disputes and violence. There are disputes between the stool and some of the families over some of the lands. There are also disputes among some of the families and among different factions of the stool family. These disputes are the causes of violence and apathy in the town and this is happening because they have limited sources of income and everybody wants to be the one to benefit from land sales.

These claims were corroborated by the Assembly Member for Bortianor. The respondents also pointed out the problem of some unscrupulous land owners leasing the same parcel of land to different lessees, or different claimants demanding 'drink money' from the lessees for the same plot of land. The effects of these include prolonged litigations at the courts as well as occasional violent clashes involving various players in the land market - chiefs, landowning families, developers and notorious land guards. Land guards are thugs who are often armed and employed by any of the players to guard lands to which they lay claim.

Indigenous and long-term settler households who have for generations depended on land for their livelihoods are probably the most adversely affected by the collapse of the customary land tenure system and the emerging urban land market. Most of them are resource-poor farmers who do not have the wherewithal to acquire land from the land market. For example, during the household survey in Bortianor, over $80 \%$ of farm households (A farm household is one that depends on agriculture either exclusively or partially as a source of livelihood) indicated that they had lost part of their farmlands; the corresponding figure at Kwashiekuma was $67 \%$.

As a result of the above developments, most farm households have been forced out of farming. For example, the proportion of surveyed households that used to farm but are no longer able to do so due to the inability to access land is $43 \%$ at Kwashiekuma and $78 \%$ at Bortianor. It is therefore not surprising that the proportion of households that currently engage in farming is only about $52 \%$ at Kwashiekuma and $17 \%$ at Bortianor (Table 3).

During the survey, farm households that still engage in farming were asked to indicate their current farm size and their farm size 25 years ago. The results show that households have experienced average farm size declines of $43 \%$ and $67 \%$ at Kwashiekuma and Bortianor, respectively (Table 3 ). Most of the interview respondents at both the municipal and community levels indicated that, only a few households, such as those of the chiefs and their elders and family heads, benefit from the allocation of

Table 3: Selected indicators of household engagement in earming at Kwashiekuma and Bortianor

\begin{tabular}{lcc}
\hline Indicator & Kwashiekuma & Bortianor \\
\hline $\begin{array}{l}\text { Proportion of households that used to farm but are no longer farm- } \\
\text { ing due to inability to access land }\end{array}$ & $42.6 \%$ & $78.0 \%$ \\
Proportion of households that are currently engaged in farming & $51.7 \%$ & $17.3 \%$ \\
Av. farm size of farm households 25 years ago & 3.5 acres & 3 acres \\
Av. farm size of farm households currently & 2 acres & 1.0 acres \\
Percentage decline in average farm size & $(42.9 \%)$ & $(66.7 \%)$ \\
\hline
\end{tabular}

Source: Field Survey, 2015 


\section{Oduro and Adamtey}

farmlands for sand winning and urban development, and the living conditions of most residents are getting worse. Responses generated through key informant interviews and focus group discussions with regard to the effects of residents' vulnerability are summarised in Box 1.

The responses in Box 1 show that, respondents were of the view that the conversion of farmlands to sand mines or urban development has had adverse effects on residents. They cited unemployment, declining household income, household food insecurity and poverty as the main negative effects. In particular, there was a general consensus among respondents that, although urban expansion had created new economic opportunities, the collapse of crop farming had given rise to unemployment and worsened the poverty situation among indigenes and long-term settlers. According to an official of Ga South Municipal Assembly, although there are no statistics to prove it, youth unemployment is very high at Bortianor and this is mani- fested by the idling about of many of the youth. At Kwashiekuma, one male resident stated that:

"I used to be a 'real' farmer in the 1980s and $90 \mathrm{~s}$, when I could harvest barns of corn. However, today I can hardly produce enough to feed my family."

The above revelations were confirmed by results of the household survey. As Table 4 shows, about $21.3 \%$ of the economically active adult household members at Kwashiekuma indicated that they had become unemployed due to the conversion of farmlands, compared to an official unemployment rate of $8.5 \%$ in the Ga West Municipality (GSS, 2014a). At Bortianor, the proportion of economically active adult household members who were unemployed for the same reason was $14.5 \%$, which was higher than the unemployment rate of $8.5 \%$ in the Ga South Municipality (GSS, 2014b). Table 4 also shows that an overwhelming majority of households in both communities reported that their incomes were declining or they

\section{Municipal officials}

- Although sand winning and leasing of land for residential development generate a lot of income, only a few people (i.e. the sand winners and households of chiefs, elders and family heads) receive the benefits. Most of these people do not even live in the communities permanently.

- The living conditions of most residents are worse than before. Although poverty has been endemic in these communities, the situation has become worse because the residents can no longer farm and they do not possess skills that would allow them to switch to other occupations. Many farm households cannot even produce enough food to feed themselves throughout the year.

\section{Community respondents}

- The conversion of farmlands to urban development has created unemployment and high levels of poverty. This is because farming used to be the main occupation of most residents and, in the absence of farming, there are no meaningful, alternative employment opportunities.

- Now, many households are not able to meet their basic needs and a lot of them have to buy food from Accra and other communities, particularly during the lean season. The situation has also forced a lot of the youth to migrate to Accra.

Box 1: Municipal officials' and community respondents' assessment of the effects of Accra's growth on living conditions

Source: Field Survey, 2015

Journal of Science and Technology ㅇ KNUST April 2017 
Vulnerability of indigenous communities in emerging urban land markets ... 95

had difficulty in accessing food due to the conversion of farmlands. Only a small proportion of households $(6.7 \%$ at Kwashiekuma and $10.8 \%$ at Bortianor) reported that their incomes were rising due to the conversion of farmlands. In addition, most household heads $(83.3 \%$ at Kwashiekuma and $50.8 \%$ at Bortianor) indicated that the expansion of Accra had had a negative effect on their household or community. It is also significant to note that while over $32 \%$ of household heads at Brotianor indicated that the expansion of Accra had had positive effects on their household or community, less than $7 \%$ of their counterparts at Kwashiekuma indicated so. This could be attributed to the fact that, because of its relatively close proximity to Accra, some residents of Bortianor have found alternative sources of livelihoods, especially in building construction and trading (Table 1), however, the same cannot be said of Kwashiekuma where such opportunities do not exist.

\section{Measures to protect residents}

In view of the high level of vulnerability of residents due to the ravages of the evolving urban land market and the inevitable collapse of the customary land tenure system, we were interested in finding out whether there are any mechanisms in place, at either the community or municipal level, to protect the residents. The results show that there are no such mechanisms.
According to officials of the two municipalities, it is the responsibility of the Municipal Assemblies to preserve and protect farmlands from urban development through the preparation and enforcement of comprehensive land use plans. However, the Physical Planning Department, which is supposed to help the Assemblies carry out this mandate, has not been resourced to do so. The result is that the chiefs engage the services of non-professional planners to prepare planning schemes for their communities with little or no effort to preserve farmlands, or even make provision for other non-residential land uses. For example, according to an official of the Physical Planning Department of the Ga South Municipal Assembly:

"So far none of the planning schemes prepared by the chiefs for communities in this area has land reserved for agriculture. The schemes focus mainly on residential development. The chiefs do not consider anything other than residential development, and this is due to their desire to maximize their earnings from the allocation of plots. Unfortunately, the Municipal Assembly has failed to get the chiefs to make adequate provision in their planning schemes for uses such as agriculture, markets, schools and health facilities".

Table 4: Effects of the conversion of farmlands to sand mines or urban development

\begin{tabular}{|c|c|c|}
\hline Effect & Kwashiekuma & Bortianor \\
\hline Household members unemployed due to farmland conversion & $21.3 \%$ & $14.5 \%$ \\
\hline Households with rising income due to farmland conversion & $6.7 \%$ & $10.8 \%$ \\
\hline Households with declining income due to farmland conversion & $80.0 \%$ & $73.8 \%$ \\
\hline $\begin{array}{l}\text { Households with difficulty in accessing food due to farmland con- } \\
\text { version }\end{array}$ & $86.7 \%$ & $80.0 \%$ \\
\hline $\begin{array}{l}\text { Household heads who think Accra's expansion has had negative } \\
\text { effects on household/ community }\end{array}$ & $83.3 \%$ & $50.8 \%$ \\
\hline $\begin{array}{l}\text { Household heads who think Accra's expansion has had positive } \\
\text { effects on household/ community }\end{array}$ & $6.7 \%$ & $32.3 \%$ \\
\hline
\end{tabular}

Source: Household survey, 2015 
Moreover, the investigations revealed that neither the central government nor the municipal assemblies had any concrete policies in place to protect poor peri-urban residents from farmland conversion, and the situation is not different at the community level. During key informant interviews, spokespersons of both chiefs indicated that although residents are often not compensated for losing their farmlands, proceeds from 'drink money' and rents paid by sand winners and developers are invested in projects that benefit the whole community, but there was no evidence to that effect. Indeed, other respondents disputed this claim.

The fieldwork also revealed that, when the chiefs or family heads lease farmlands to sand contractors or developers, affected farmers are at best given a period of time to harvest their crops and vacate their farms. There were reported cases of situations in which crops were destroyed by sand winners and developers because either the crops were not mature for harvest or they were perennial crops such as cashew, mangoes and coconut. Although sand winners or developers sometimes pay compensations for the crops destroyed, such compensations are meagre and the farmers become more impoverished. Asked why the affected residents do not go to court to seek fair compensations, or even stop the conversion of farmlands to non -agricultural uses, the recurring response was that they were too poor and powerless to litigate with the chiefs, family heads, sand contractors or developers.

\section{DISCUSSIONS AND RECOMMENDA- TIONS}

The study has revealed that indigenous and long-term residents of peri-urban communities are highly vulnerable due to the emerging urban land market and the changing customary land tenure system resulting from rapid urban growth. Their vulnerability stems from the fact that the customary land tenure system operates on the principle of communal ownership without absolute tenure security for the individual community/family member or household. In other words, "customary land is not subject to personal ownership, although use-rights are alienable within and between members of the community" (Fisher, 1993 cited in Payne, 1996: 3; see also Toulmin, 2006). Instead, decisions regarding the alienation of land title are vested in the leadership (chiefs, elders, clan heads, etc) who are symbols of "residuary, reversionary and ultimate ownership of all land held by the collective" (Mabogunje, 1992 cited in Mends and De Meijere, 2006) and are assumed to act in the collective interest of the rest of the community. In the past, major land decisions taken by custodians of customary land, "especially disposition of any portion of the communal land to non-members of the land holding community, require (the concurrence of the principal elders as well as consultations with those using the land" (Fobih, 2004: $5)$.

However, as is the case at Kwashiekuma and Bortianor, "this principle is no longer tenable, as decisions on granting land to non-members [of the group or community] are taken without any reference to the occupiers of the land" (Fobih, 2004: 6).

This study has revealed that the decision of these leaders to permit the conversion of farmlands to urban development by outsiders is no longer informed by the spiritual and social considerations, or communal interests, that used to prevail in African societies. For example, the belief that land belongs collectively to the dead, living and unborn members of the community (Ollennu, 1962) no longer appears to be a key consideration in land allocation decisions. Instead, the decisions of the leaders of today's peri-urban communities are informed by profit motives and other economic considerations that pertain to the highly monetized urban society.

The economic reality is that, as a city grows in population and physical size, the value of land in peri-urban areas appreciates and it becomes more profitable to convert farmlands close to the city to residential and other urban uses 
Vulnerability of indigenous communities in emerging urban land markets ... 97

(Cavailhès and Wavresky, 2003). This phenomenon is explained by Alonso's (1964) bid rent theory, which suggests that the value of land increases with proximity to the city centre. That means, as the city draws closer to periurban communities through physical expansion, land rent in those communities increase and agriculture, which hitherto was the main economic activity, is outbid by residential, commercial and other urban activities. Eventually, agricultural activities in peri-urban communities located close to the city give way to housing and other urban developments (Brueckner, 1987; Kraus, 2003; McMillen, 2006; Romein et. al., 2009). Similar developments have been reported in peri-urban areas of other African cities such as Kumasi in Ghana (Aberra and King, 2005) and Banjul in Gambia (Roth et al 1996 cited in Rakodi 1999), where land is taken from indigenous residents and leased to 'outsiders' who have the means to pay high rents charged by customary land 'owners'.

The vulnerability of residents of peri-urban communities due to the emergence of the urban land market and the changing customary land tenure system has had adverse effects on their quality of life. While chiefs and heads of landowning families capitalize on the rising value and demand for land to make money by leasing out plots to developers, speculators and sand winners, other indigenous and long-term residents become worse off. These indigenous and long-term residents, who are among the millions of low-income Ghanaians who make a living directly from land and whose tenure security is not effectively protected, become more impoverished as a result of land conversion (Aryeetey et. al.,2007). As some scholars have observed, the commoditization of land in Africa, which undermines customary tenure structures, leads to "increased marginalization and landlessness as the elite took advantage of the less powerful" (Nkwae, 2006: 35). The implication is that peri-urban residents are unfairly made to bear the brunt of urbanization and land commoditization. Without any form of protection from the forces of urbanization and farm- land conversion, many of them eventually add to the already large numbers of poor and unemployed people in the city. The fact that about 6,000 hectares of Ghana's farmlands, especially those located on the fringes of cities, are converted to urban uses every year (Fobih, 2004) is an indication of the magnitude of this problem.

To address the above problems, there is the need for urban policies that are designed to protect peri-urban residents who directly depend on land to make a living. Such policies should include the restoration of farm households whose lands are converted to urban development. There should also be laws that compel chiefs and family heads to pay compensation to such farm households not only for the loss of crops but also for the loss of access to the land. In addition to monetary compensation, government should support residents of indigenous peri-urban communities with alternative sources of livelihoods other than farming. For example, unemployed youths in such communities could be trained in vocational and entrepreneurial skills in areas such as construction, small-scale industries and trading. There is also the need for the preservation of farmlands. As part of their land use planning and development control functions, the various municipal assemblies should demarcate tracts of fertile land and designate them as special zoning districts exclusively reserved for farming.

\section{CONCLUSION}

The purpose of this study was to examine the vulnerability of residents of indigenous communities in peri-urban Accra due to the emerging urban land market as those communities get engulfed by the rapidly expanding urban space. It is revealed that both indigenous and longterm residents, most of whom were farmers, are highly vulnerable in the sense that they lose their farmlands without any measures in place to protect them from the collapsing customary land tenure system and the negative effects of the new urban land market. This has negatively impacted on their quality of life, especially with respect to employment and income. 
To address the adverse effects of the changing land tenure system, there is the need for urban policies designed to protect peri-urban residents who directly depend on land to make a living. Such policies should focus on supporting residents of indigenous peri-urban communities with alternative sources of livelihoods other than farming. For example, the youths in such communities could be trained in vocational and entrepreneurial skills in areas such as construction, small-scale industries and trading. There should also be laws that compel chiefs and family heads to allocate a portion of the proceeds realised from the sale of plots as compensation to farm households who lose their farmlands. The compensation amount, which should be in respect of both the loss of crops and the loss of access to the land, should be included in the pricing of plots. There is also the need for the preservation of farmlands. As part of their land use planning and development control functions, the various municipal assemblies should demarcate tracts of fertile land and designate them as special zoning districts exclusively reserved for farming.

\section{REFERENCES}

Aberra, E. and King, R. (2005). Additional knowledge of livelihoods in the Kumasi peri urban interface (KPUI), Ashanti region, Ghana. London: Development Planning Unit (DPU), University College London.

Alonso, W. (1964). Location and land use: Toward a general theory of land. Cambridge: Harvard University Press.

Antwi, A. and Adams, J. (2003). Economic rationality and informal urban land transactions in Accra, Ghana. Journal of Property Rese arch, 20 ( 1):6 7-90. D O I : $10.1080 / 09599910210159398$

Aryeetey, E., Ayee, J. R. A., Ninsin, K. A. and Tsikata, D. (2007). The politics of land tenure reform in Ghana: From the crown lands bills to the Land Administration Project. Technical Publication No. 71, Institute of
Statistical, Social and Economic Research (ISSER), University of Ghana, Legon, Ghana.

Blocher, J. (2006). Building on custom: Land tenure policy and economic development in Ghana. Yale Human Rights and Development Law Journal, 9: 166-202.

Brueckner, J. K. (1987). The structure of urban equilibria: A unified treatment of the MuthMills model. In E. S. Mills (Ed), Handbook of regional and urban economics, 2: 821845. North-Holland, Amsterdam.

Bugri, J. T. (2008). The dynamics of security, agricultural production and environmental degradation in Africa: Evidence from stakeholders in north-east Ghana. Land Use Policy, 25(2): 271-285

Cavailhès, J. and Wavresky, P. (2003). Urban influences on peri-urban farmland prices. European Review of Agricultural Economics, 30(3), 333-357. http://dx.doi.org/10.1093/ erae/30.3.333.

DFID (1999). Sustainable livelihoods guidance sheets: Framework. Department for International Development, London. Retrieved from http://www.nssd.net/pdf/sectiono.pdf on $8 / 05 / 2015$.

Dordaa, F. (2012). Urban planning and management through effective development control systems: The case of the Bolgatanga $\mathrm{Mu}-$ nicipality. An unpublished master's thesis submitted to the School of Graduate Studies, Kwame Nkrumah University of Science and Technology, Kumasi.

Fobih, D. (2004). The Significance of secure access to land for the livelihoods and food security of Africa's farmers and the urban poor. A paper presented at a conference on Land in Africa: Market Asset, or Secure Livelihood? Church House, Westminster, London, November 8-9 2004 
Ghana Statistical Service (GSS) (2013). 2010 Population and housing census: Regional analytical report (Greater Accra Region). Accra: GSS.

GSS (2014a). 2010 Population and housing census: District analytical report (Ga West Municipality). Accra: GSS.

GSS (2014b). 2010 Population and housing census: District analytical report (Ga South Municipality). Accra: GSS.

Grant, R. (2007).Geographies of investment: How do the wealthy build new houses in Accra, Ghana? Urban Forum, 18(1): 31-59.

Kasanga, R. K. (1998): Land tenure and the development dialogue: The myth concerning communal landholding in Ghana. Occasional Paper No. 19, Department of Land Economy, University of Cambridge, Cambridge.

Kassanga, R. K., J. Cochrane, R. King and M. Roth (1996). Land markets and legal contradictions in the peri-urban area of Accra, Ghana: informant interviews and secondary data investigations. LTC Research Paper 127. Madison: University of WisconsinMadison.

Krantz, L. (2001). The sustainable livelihood approach to poverty reduction: An introduction. A paper commissioned by the Swedish International Development Cooperation Agency (SIDA), Division for Policy and Socio-Economic Analysis.

Kraus, M. (2003). Monocentric cities. Working papers in economics, Economics Department, Boston College.

Mahama, C. and Antwi, A. (2006). Land and property markets in Ghana. A paper presented at the 2006 World Urban Forum held from June 19-23, 2006 in Vancouver, Canada.
McMillen, D. (2006). Testing for monocentricity. In R.J. Arnott and D. P. McMillen (eds), A companion to urban economics. Maiden: Blackwell Publishing.

Mends, T. M. and J. De Meijere (2006). A Study of the institution of the customary land tenure system in the supply of property rights for urban development - An example of Accra, Ghana. A paper presented at the $5^{\text {th }}$ FIG Regional Conference in Accra, Ghana, March 8-11, 2006.

Nkwae, B. (2006). Conceptual framework for modelling and analysing peri-urban land problems in Southern Africa. Technical Report No. 217, Department of Geodesy and Geomatics Engineering, University of New Brunswick, Fredericton, N.B., Canada.

Ollennu, N. A. (1962). Principles of Customary land law in Ghana. London: Sweet and Maxwell.

Payne, G. (1996). Urban land tenure and property rights in developing countries: A review of the Literature. The Overseas Development Administration. Retrieved from http:// www.alnap.org/pool/files/overseasdevelopment-administration-1996-urban-land -tenure-and-property-rights.pdf, 13/09/2015.

Platteau, J-P. (1996). The evolutionary theory of land rights as applied to Sub-Saharan Africa: A critical assessment. Development and Change, 27(1): 29-86. DOI: 10.1111/j.14677660.1996.tb00578.x

Quarcoopome, S.S. (1992). Urbanisation, land alienation and politics in Accra. Research Review NS, 8:1 \& 2 .

Rakodi, C. (1999). Poverty and wellbeing in the peri-urban interface of developing country cities: A review. Programme development report PD070. Hemel Hempstead: Natural Resources Systems Programme (NRSP), UK Department for International Development 
(DFID).

Rakodi, C. (2002). A livelihood approachconceptual issues and definitions. In Rakodi, C. with Tony Lloyd-Jones (eds): Urban livelihoods: A people-centred approach to reducing poverty. London: Earthscan Publications Ltd.

Romein, A., Verkoren, O. and FernandezMaldonado, A. (2009). Polycentric metropolitan form: application of a 'Northern' concept in Latin America. Footprint: Metropolitan Form, (5): 127-128. Retrieved from h t t p : / / d s p a c e . li b r a r y . u u . n $1 /$ handle/1874/289110 on 15/02/2015

Shuttleworth, M. (2008). Case study research design. Retrieved [03/18/15] from Experiment Resources: http://www.experimentresources.com/case-study-researchdesign.html.
Toulmin, C. (2006). Securing land rights for the poor in Africa - Key to growth, peace and sustainable development. A paper prepared for the Commission on the Legal Empowerment of the Poor. New York, NY, USA.

Twigg, J. (2001). Sustainable livelihoods and vulnerability to disasters. Disaster Management Working Paper 2/2001, the Disaster Management Institute (DMI)

Twum-Baah, K. A. (2000). Population growth of Mega-Accra - Emerging issues. In R. Mills-Tettey and K. Adi-Dako (eds.), Visions of the city: Accra in the 21st century. Accra: Woeli Publishing Services.

Yin, R. K. (2003). Case study research: Design and methods. Los Angeles: SAGE Publications. 